\title{
LXII. Hints to cultivators of the sugar cane
}

\section{Blackford Esq.}

To cite this article: C. Blackford Esq. (1814) LXII. Hints to cultivators of the sugar cane, Philosophical Magazine Series 1, 43:192, 289-292, DOI: 10.1080/14786441408638027

To link to this article: http://dx.doi.org/10.1080/14786441408638027

曲 Published online: 27 Jul 2009.

Submit your article to this journal 준

Џ Article views: 2

Q View related articles ¿ 
leech; the former being a section through the middle of it, and the latter showing its outside; it is a brass tube $A$, having a cover $B$ at one end, through which a screw $\mathrm{C}$ passes; this screw has a circular piece of brass $a$ fixed upon it, which slides in the tube, and carries the three piercers $b ;$ a spiral spring surrounds the screw, and presses upon the piece $a$, so as to force it always towards the open end of the tube; but a milled nut $l$, upon the screw C, prevents it going too far; $d$ is a small spring eatch, fixed within side the tube, and having a button $\epsilon$ proceeding from it, through the side of the tube; the catch passes through a small square hole in the piece $\alpha$, and has a kind of hook formed upon it, of a similar shape to the hook of a door latch; this, when the screw $\mathbf{C}$ is drawn back, by pulling its nut $b$, retains it as shown in the figure, the spring being fully bent; and in this state the open end of the tube is to be applied upon the part where the bleeding is to be performed; then, by pressing upon the head of the button $e$, the spring catch $d$ is discharged, and the spring throws the piece $a$ forward, eausing the points $b$ to enter the skin, and make the punctures, the depth of which is regulated at pleasure by the nut $b$; which being screwed along the screw $\mathrm{C}$, allows the points to protrude as far beyond the end of the tube as the operator's judgement directs, when the spring is discharged.

Fig. 1 . is the syringe and cupping-glass, to be applied after this operation; $\mathrm{E}$ is a small glass bell, of which there are several of different sizes provided; it has a brass cap $f$, terminating in a screw $g$, by which it is attached to the end $F$ of the syringe $G$; this exhausts the air, when the handle $H$ is drawn out in the usual manner; a small valve of bladder being tied over the aperture in the end of the screw $g$, to prevent the re-entrance of the air when the handle of the syringe is returned; $h$ is a small stopcock, to shut up the passage when the exhaustion is complete, as the valve alone would sonetimes be insufficient to prevent the leakage of the air when the syringe is unscrewed.

\section{Hints to Cultivators of the Sugar Cane. By C. BLACK- Ford, Esq. of Jamaica*.}

T

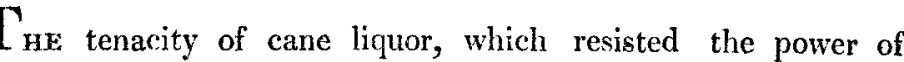
white lime to decompose and neutralise its substance, having been suggested to me, and in some instances confirmed by my own observation, it has occasioned me much painful solicitude to divine why the effect should not be the same in all cases. I was well aware, that the richer the liquor the more temper lime was necessary; the weaker juices more readily deposited its more

* From the Jamaica Royal Gazette of November 1813.

Vol.43. No.192. April 1814.

$\mathrm{T}$

ponderous 
ponderous impurities, and a comparatively small quantity of white lime effected separation and precipitation. Hence, in all cases of the lighter juices, an error could not happen, and the temperglass, when used, was a ready guide. Having lately had an opportunity of perusing a work entitled "Elements of Natural History and Chemistry," and guided by other references which it has been my study to embrace, I find there are earths and stones that mav be calcareous without having the power to effervesce with acids; and my late experience has confirmed the fact, that even the best white lime, after having been exposed for some time to the air, will lose that quality which I conceive to be essential in decomposing rich, matured, good cane juice. From the frequent stoppage of fire, occasioned by the mill by no means supplying the three small vessels on this estate, the liquor often got tainted in the boilers, which its smell immediately made known. And here I must remark, that neutralised liquor assumes a new character, and, I have every reason to think, yields soon to the more powerful agent, acidity, and can only be restored by a free use of active lime applied to the boiled liquor, simply putting it into the ladle therewith, and straining or rather throwing it on a skimmer on the liquor in the coppers; nor should the operator apply lime with too cautious a hand. I take the liberty to affirm, that half a pint, or even a whole one, applied over and above in the receiver in tempering, would not have any other effect than that produced by a like quantity of salt in curing a large round of beef. So also, as a restorative, should the liquor, by staying process, lean to taint, apply liberally temper lime, to destroy the acid, and rather let the smell of alkali predominate;-do not fear the result, as no discolouring of the sugar nor scaling the tache will take place. But to come more immediately to the point : an excellent small kiln of white lime, composed of the coarse grained common limestone, and calcined by the strongest hard wood, was burnt on this estate. Previously to commencing crop this year, several hogsheads were headed up, and some was deposited in the boiling-house in casks; one burst very soon after, which for a time served the purpose of temper; but in a little I found it to lose its proper effect. My late reading had given me the idea of effervescence. On applying a half pint, or rather more, of this lime to the boiling liquor, it had not that quality, though it approached to granulation, but not in so active a degree as it ought. I caused another cask to be used, and found that with a much less quantity, thrown into aladle of liquor, the effervescence was so strong and turbulent, as to force its way over the side of the ladle, and was more efficacious. Hence 1 infer, that too little attention is paid to the quality of the stone, and the state of the temper lime commonly used. From the works 
which I have had the opportunity of perusing, I am induced to believe, that, if large vessels were in use, alum would very essentially and powerfully resist fermentation. From analogy, in the animal and vegetable kingdom, I conclude, that as alum is found to resist putrefaction in a greater degree by forty times than common sea-salt, so I think it may act as a preservative from the great evil to be aroided in the manufacture of our grand staple, sugar.

Great Pond Estate, St. Ann's, June 9.1813.

C. BLACKFORD.

June 29.-Since my last communication I made the following experiment to prove how far alum acted in resisting fermentation by applying it to cane-juice in the manufacture of sugar, which I briefly subjoin :-On the 23d inst. I filled a large clecanter with cane-juice as it flowed from the mill, and five three-onnce phials, prepared, the first, as a standard from the mill ; into the second I put a sinall portion of alum; with the third I took clarified liquor from the receiver, in which there was also some alum; the fourth contained simply clarified liquor; and the fifth cane liquor out of the decanter, satur.tel with white lime. I then filled ip the decanter with Seville orange-juice. The decanter was in a rapid fermentation the next morning. The first phial was not observed to ferment on the $24 \mathrm{th}$, but on the morning of the $2 \tilde{5}$ th it was visible; the second, with the alum applied to it, has not to this day any sign of fermentation; the third has not yet shown any degree of agitation, though both the latter smell and taste a little acid; the fourth fermented on the 26 th; and the fifth did not show any sign of fermentation until the 28th, and then slowly. Thus have I endeavoured in a crude state to ascertain the power of alum to counteract the great evil to be avoided in making sugar, leaving to those who are more able to determine with precision its due effect and properties, and humbly hoping that the attempt, however imperfect, may be considered as an offering of one using his best endeavours to promote useful knowledge.

July 7.-The phial alumed from the receiver of clarified liquor was observed to ferment on the morning of the lst inst. The phial also alumed from the cane-juice as it flowed from the mill, began to be in a state of fermentation on the $2 \mathrm{~d}$ inst. being from the $23 \mathrm{~d}$ of June, both days inclusive, a period of ten days : an incontrovertible proof of the quality of alum as a powerful cuunteractor of fermentation. Many other grand advantages may be derived from it in the manufacture of sugar. I could make some observations that arose during the trial, but I feel I have been already too prolix.-I shall only observe, that all the phials were exposed to the same situation as to air; being also uncorked, 
and the others ccased to ferment some days before those last mentioned showed the least sign of agitation. The alum brightened the liquor; consequently, it would have the same effect in the sugar. This may give rise to further experiments by those more capable of elucidating its properties and effects, should you consider this as worthy of publication.

LXIII. Experiments upor Mushrooms. By M. VAUQUblin*. M. Jaume Sr. Hularze, so well known by his botanical acquirements, having requested me to submit to chemical analysis three kinds of poisonous mushroonis, viz. the agaricus theogalu's, lulboszis, and muscarins, I turned to the memoir of M. Braconnot on the subject, inserted in the lxxixth volume of the Annales de Chimie.

The results obtained by this chemist appeared to me to be so interesting that I inmediately resolved to verify them by experiments, and with this view I began an accurate analysis of the common mushroom which is to be procured daily in the markets of Paris.

It is to the common mushroom, therefore, that my present work chiefly refers. I shall subjoin the results obtained from the three kinds of mushroom above mentioned.

M. Braeonnot discorered in mushrooms a great number of principles; the most prominent of which I shall enumerate here: for instance, in the agaricus volvaceus there are, according to lim, lst, Fungine, or the fibrous part common to all muhrooms. 2d, Gelatine. 3d, Albumen. 4th, A particular kind of erystallizable sugar. 5th, Oil. 6th, Wax. 7 th Adipocire. 8th, Benzoic acid. 9th, A very evanescent deleterious principle. $10 \mathrm{th}$, Finaily Salts, such as phosphates, acetates and muriates of potash.

In the other species he sometimes found new acids, an unknown animal matter, and animal mucus.

\section{ANALYSIS OF THE COMMON EATING MUSHROOM.}

Agaricus campestis. After having skinned it, it was pounded in a marble mortar, adding a little cistilled water, and the moisture was afterwards expressed.

These manipulations were repeated until the water which was arded came off almost colourless.

The juice was filtered : it had a slight red colour, and the husks $($ marc $)$ were set aside in order to be treated with alcohol, as afterwards described.

$$
\text { * Annales de Chimie, tome lxxxv. p. } 5 .
$$

